\title{
Perubahan Penggunaan Lahan di Kawasan Keamanan dan Ketahanan Pangan di Kabupaten Sleman
}

\author{
Farida Afriani Astuti ${ }^{*}$, Herwin Lukito ${ }^{2}$ \\ 1,2 Prodi Teknik Lingkungan, UPN "Veteran" Yogyakarta
}

\section{Article Info}

\section{Article History}

Dikirim 3 Oktober 2019

Diterima 10 Januari 2020

Terbit 30 Januari 2020

\section{Keywords:}

extensive land-use change; form of land-use; area of food security and sustainability

luas perubahan penggunaan lahan; bentuk perubahan penggunaan lahan; kawasan keamanan dan ketahanan pangan

\begin{abstract}
Abstrak
Kabupaten Sleman memiliki banyak daya tarik yang memicu terjadinya urbanisasi yang dapat terlihat dari fenomeno perubahan penggunaan lahan. Perubahan penggunaan lahan di Kabupaten Sleman terjadi pada kawasan keamanan dan ketahanan pangan yang terdiri dari Kecamatan Moyudan, Minggir, Sayegan, Godean, Mlati, dan Tempel. Fenomena perubahan penggunaan lahan penting untuk dikontrol dan dikendalikan karena kawasan tersebut memiliki peran penting bagi ketahanan pangan di Kabupaten Sleman. Metode penelitian yang digunakan adalah metode deskriptif. Di dalam metode deskriptif terdapat metode survey yang digunakaan untuk mengetahui kondisi eksisting penggunaan lahan di daerah penelitian. Sedangkan untuk perubahan penggunaan lahan pada kawasan keamanan dan ketahanan pangan di Kabupaten Sleman dari Tahun 2012 sampai Tahun 2018 diperoleh dengan metode overlay peta penggunaan lahan yang diperoleh dari Citra Quickbird pada tahun tersebut. Perubahan penggunaan lahan pada kawasan keamanan dan ketahanan pangan Kabupaten Sleman mencapai $57,33 \mathrm{~km} 2$ atau $33,93 \%$ dari luas total daerah penelitian. Perubahan penggunaan lahan didominasi oleh perubahan lahan sawah menjadi hutan produksi seluas $15,05 \mathrm{~km} 2$. Faktor pendorong adanya perubahan penggunaan lahan tersebut adalah produktivitas pertanian sawah yang semakin menurun tiap tahunnya.
\end{abstract}




\section{PENDAHULUAN}

Kabupaten Sleman sebagai salah satu wilayah di Provinsi DIY tidak luput dari fenomena urbanisasi. Urbanisasi didefinisikan sebagai proses menjadi kawasan perkotaan, perubahan pekerjaan dari bertani menjadi yang lain, dan perubahan dalam pola perilaku manusia (Pontoh dan Kustiawan, 2009). Banyaknya daya tarik yang dimiliki Kabupaten Sleman sebagai pusat pendidikan, tujuan tempat tinggal, tujuan wisata dan tempat perkembangan budaya menjadikan urbanisasi tidak dapat dihindari. Data Badan Pusat Statistik (BPS) mencatat pada Tahun 2016 Kabupaten Sleman terdapat 29.209 jiwa migrasi masuk dan 13.601 jiwa migrasi keluar. Banyaknya migrasi masuk di Kabupaten Sleman menjadi salah satu indikator urbanisasi yang terjadi di Kabupaten Sleman, yang berakibat banyaknya alih fungsi lahan pertanian menjadi lahan terbangun ataupun fungsi lainnya.

Fenomena alih fungsi lahan penting untuk dikontrol/ dikendalikan karena dalam UU Nomor 41 Tahun 2009 tentang Perlindungan Lahan Pertanian Pangan Berkelanjutan (LP2B) Pasal 19 disebutkan bahwa LP2B merupakan bagian dari penetapan Rencana Detail Tata Ruang (RDTR) yang harus dilindungi. Perlindungan terhadap kawasan pertanian sudah ditetapkan oleh Rencana Tata Ruang Wilayah (RTRW) Kabupaten Sleman Tahun 2011 - 2031 melalui penetapan kawasan strategis fungsi keamanan dan ketahanan pangan wilayah dengan luas kurang lebih 4.886 hektar yang terdiri dari Kecamatan Moyudan, Minggir, Sayegan, Godean, Mlati, dan Tempel.

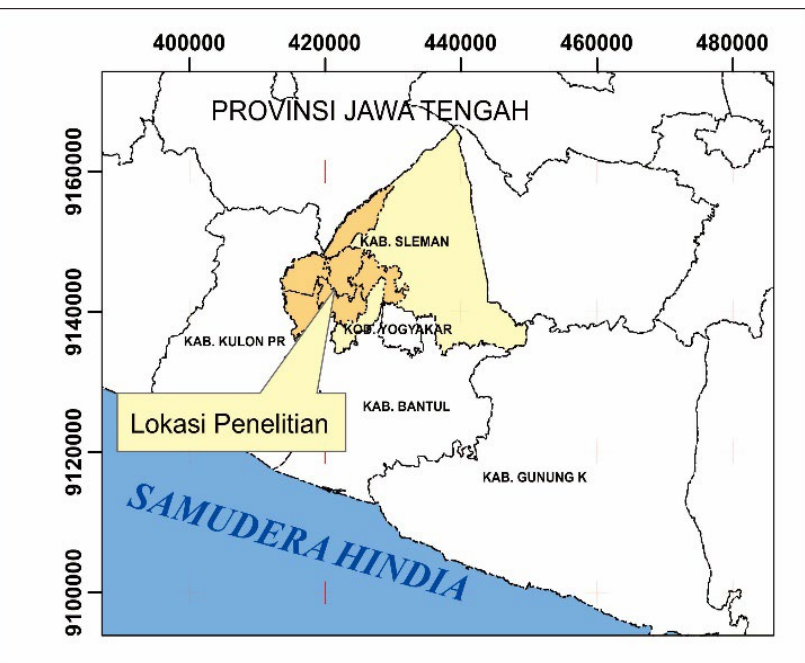

Gambar 1. Peta lokasi penelitian berada pada 6 Kecamatan di Kabupaten Sleman

Pertahanan kawasan ketahanan pangan menjadi sangat penting karena menurut data Indeks Ke- tahanan Pangan Indonesia (IKP) Tahun 2018 menyebutkan bahwa Kabupaten Sleman menduduki peringkat 11 dari 416 kabupaten seluruh Indonesia dengan score 83, 49. Skore tersebut menunjukkan bahwa wilayah Kabupaten Sleman memiliki ketahanan pangan paling baik dengan kriteria score $>$ 75,68 . Tujuan penelitian ini adalah menghitung luas perubahan lahan di kawasan keamanan dan ketahan pangan di Kabupaten Sleman. Perhitungan luas perubahan lahan tersebut bisa dijadikan sebagai alat kontrol pengendalian alih fungsi lahan yang sedang terjadi. Daerah penelitian berada pada 6 kecamatan di kabupaten Sleman yaitu Kecamatan Minggir, Moyunan, Sayegan, Godean, Mlati dan Tempel (Gambar 1).

\section{METODE PENELITIAN}

Metode penelitian yang digunakan adalah metode survey dan pemetaan serta metode deskriptif. Metode survey dan pemetaan digunakan untuk mengetahui kondisi eksisting penggunaan lahan pada kawasan keamanan dan ketahanan pangan. Metode deskriptif pada penelitian ini digunakan untuk menjelaskan luasan dan hasil analisis perubahan penggunaan lahan yang terjadi pada kawasan keamanan dan ketahanan pangan. Metode deskriptif adalah suatu metode dalam meneliti status sekelompok manusia, suatu objek, suatu set kondisi, suatu sistem pemikiran, ataupun suatu kelas peristiwa pada masa sekarang (Nasir, 2005). Di dalam metode deskriptif dilakukan juga metode survey untuk mendapatkan data dan verifikasi data.

Perubahan penggunaan lahan dihitung dalam jangka waktu 6 tahun (2012-2018). Luas perubahan penggunaan lahan pada Kawasan Keamanan dan Ketahanan pangan di Kabupaten Sleman diperoleh dengan metode overlay peta penggunaan lahan diperoleh dari Citra Quickbird pada tahun 2012 dan tahun 2018. Ketelitian citra quickbird untuk interpretasi penggunaan lahan mencapai $60 \mathrm{~m}$ (Nie et al., 2011) (Kundu, Khare, \& Mondal, 2017)

Klasifikasi penggunaan lahan menggunakan klasifikasi dari Bakosurtanal. Hasil interpretasi peta penggunaan lahan di cek dilapangan dan dilakukan koreksi pada hasil interpretasi yang salah. Pengambilan sampling interpetasi citra dilakukan menggunakan sampling purposif. Peta ini kemudian dianggap sebagai peta penggunaan lahan pada tahun 2012 (gambar 2) dan tahun 2018. (gambar 3) Peta perubahan penggunaan lahan di dapat dari hasil overlay peta penggunaan lahan tahun 2012 dan tahun 2018. Alat yang digunakan adalah GPS, kompas, kamera saku, alat tulis, peta, dan kuesioner. 


\section{HASIL DAN PEMBAHASAN}

Perubahan penggunaan lahan pada kawasan keamanan dan ketahanan pangan Kabupaten Sleman mencapai $57,33 \mathrm{~km}^{2}$ atau $33,93 \%$ dari tahun 2012 sampai tahun 2018.(gambar 4) Kabupaten Sleman yang berbatasan langsung dengan Kota Yogyakarta dengan pusat perkembangan daerah yang sangat tinggi mengakibatkan pembangunan cenderung menular dan mengarah ke Kabupaten Sleman, (Rizkiani dan Sudrajat, 2015). Arah pembangunan yang menuju Kabupaten Sleman menjadi salah satu faktor pendorong terjadinya perubahan penggunaan lahan yang terjadi pada lahan sawah karena memiliki land rent yang rendah, (Habibatussolikhah,dkk, 2016).

Bentuk perubahan penggunaan lahan pada kawasan keamanan dan ketahanan pangan $\mathrm{Kabu}-$ paten Sleman memiliki hasil yang bervariatif. Kecamatan pertama yang diteliti adalah Kecamatan Moyudan. Kecamatan Moyudan memiliki 10 jenis perubahan penggunaan lahan yang dapat dilihat pada Tabel 1. Luas perubahan penggunaan lahan di Kecamatan Moyudan adalah sebesar $10,18 \mathrm{~km}^{2}$ dengan jenis perubahan penggunaan lahan terbesar adalah lahan sawah menjadi hutan seluas 2,90 $\mathrm{km}^{2}$ kemudian diikuti dengan perubahan penggunaan lahan kebun menjadi hutan seluas $1,89 \mathrm{~km}^{2}$

Kecamatan kedua adalah Kecamatan Minggir. Kecamatan Minggir memiliki fenomena perubahan penggunaan lahan yang sama dengan Kecamatan Moyudan, yaitu perubahan penggunaan lahan terbesar adalah perubahan lahan sawah menjadi hutan seluas $1,82 \mathrm{~km}^{2}$ dan diikuti perubahan penggunaan lahan kebun menjadi hutan seluas $1,33 \mathrm{~km}^{2}$. Kecamatan Minggir memiliki 15 jenis perubahan penggunaan lahan yang dapat dilihat pada Tabel 1. Luas total perubahan penggunaan lahan di Kecamatan Minggir adalah 6,72 km².

Berbeda dengan Kecamatan Moyudan dan Minggir, di kecamatan ketiga yaitu Kecamatan Sayegan memiliki 18 jenis perubahan penggunaan lahan dengan luas total sebesar $8,72 \mathrm{~km}^{2}$. Perubahan penggunaan lahan terbesar adalah sawah menjadi hutan dengan luas $4,24 \mathrm{~km}^{2}$ yang diikuti oleh perubahan sawah menjadi permukiman seperti yang terlihat pada Tabel 1. Faktor perubahan sawah menjadi hutan dikarenakan produktivitas tanaman padi yang semakin menurun tiap tahunnya. Sedangkan perubahan penggunaan sawah menjadi permukiman dipengaruhi oleh posisi strategis Kabupaten Sleman sehingga meningkatkan permintaan lahan untuk pembangunan, (Habibatussolikhah,dkk, 2016). Kecamatan Sayegan merupakan salah satu kecamatan di Kabupaten Sleman yang memiliki posisi strategis sebagai lokasi permukiman dan bahkan tempat usaha. Tempat wisata kuliner banyak dijumpai di Kecamatan Sayegan dengan dengan mengangkat tema atau ide bisnis kuliner yang mengarah ke suasana desa dengan pemandangan alam sekitar.

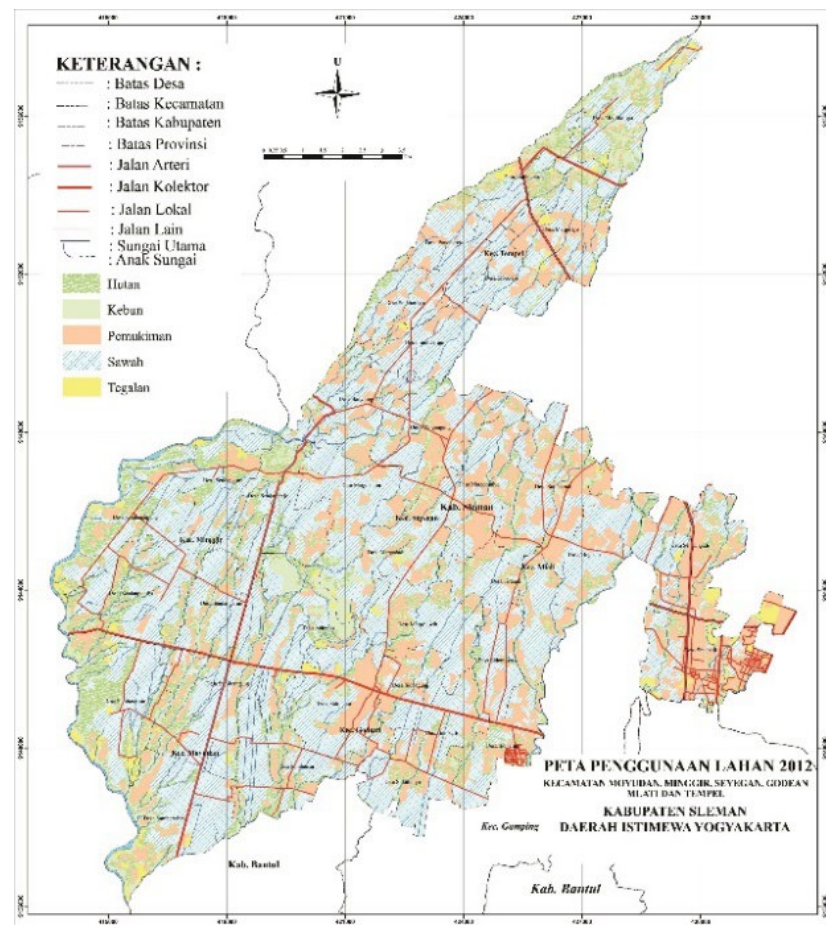

Gambar 2. Peta penggunaanlahan tahun 2012

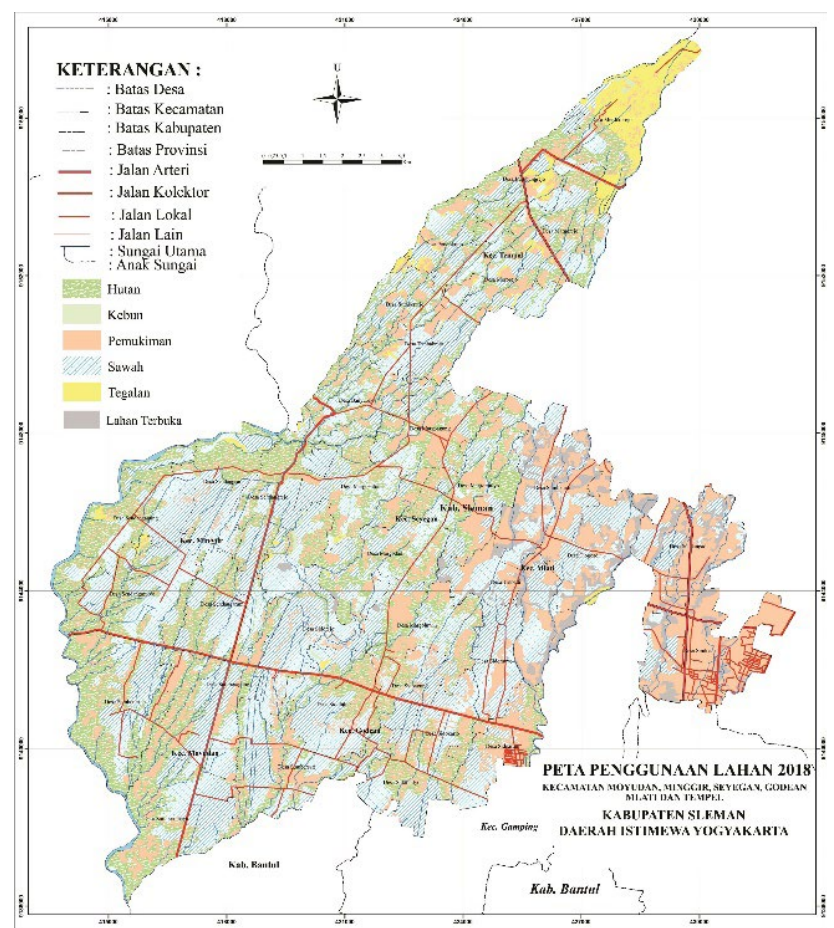

Gambar 3. Peta penggunaanlahan tahun 2018

Selain sawah menjadi hutan dan permukiman bentuk perubahan lahan sawah yang bisa dilihat dari Tabel 1. adalah perubahan penggunaan lahan sawah menjadi tegalan. Perubahan terebut bisa 
dilihat di Dusun Mriyan, Desa Margomulyo, Kecamatan Seyegan. Petani mengubah sawah menjadi tegalan untuk ditanami pohon pepaya yang dirasa lebih menguntungkan.

Kecamatan keempat yaitu Kecamatan Godean. Perubahan Perubahan penggunaan lahan di Kecamatan Godean didominasi oleh perubahan penggunaan lahan hutan menjadi sawah seluas $1,61 \mathrm{~km}^{2}$. Luas perubahan penggunaan lahan di Kecamatan Godean adalah seluas $7,25 \mathrm{~km}^{2}$ dengan 18 jenis perubahan penggunaan lahan. Adapun bentuk dan luas perubahan penggunaan lahan di Kecamatan Godean dapat di lihat pada Tabel 1. Jika di Kecamatan Moyudan, Minggir, dan Sayegan perubahan penggunaan lahan yang paling besar adalah sawah menjadi hutan, maka sebaliknya perubahan penggunaan lahan terbesar di Kecamatan Godean adalah hutan produksi menjadi sawah.Fenomena ini menunjukkan bahwa terjadi perluasan lahan pertanian sawah di Kecamatan Godean. Perluasan lahan sawah merupakan salah satu cara untuk mempertahankan fungsi kawasan keamanan dan ketahanan pangan yang sudah ditetapkan oleh pemerintah. Pertumbuhan permukiman di Kecamatan Godean yang cukup tinggi yaitu seluas $2,25 \mathrm{~km}^{2}$ harus diimbangi dengan penambahan luas lahan sawah supaya fungsi kawasan tetap bisa berjalan dengan baik.
Kecamatan kelima adalah Kecamatan Mlati. Perubahan penggunaan lahan di Kecamatan Mlati didominasi oleh perubahan lahan sawah menjadi permukiman seluas $2,45 \mathrm{~km}^{2}$ dari luas total perubahan $10,52 \mathrm{~km}^{2}$. Terdapat 16 jenis perubahan penggunaan lahan yang ada di Kecamatan Mlati seperti yang terdapat di Tabel 1. Perubahan fungsi lahan menjadi permukiman di Kecamatan Mlati juga diikuti oleh perubahan lahan sawah menjadi lahan terbuka. Tingginya kebutuhan lahan untuk permukiman di Kecamatan Mlati dipengaruhi oleh banyaknya pendatang sebesar 2.199 jiwa (BPS,2016).

Tingginya daya tarik yang dimiliki oleh Kecamatan Mlati sebagai kawasan perkotaan juga menjadi faktor pemicu adanya perubahan penggunaan lahan, salah satunya di Desa Sinduadi.Kecamatan keenam adalah Kecamatan Tempel. Perubahan penggunaan di Kecamatan Tempel didominasi oleh perubahan sawah menjadi hutan dengan luas $4,69 \mathrm{~km}^{2}$ dari luas total $13,89 \mathrm{~km}^{2}$. Terdapat 15 jenis perubahan lahan seperti yang terlihat pada Tabel 1. Perubahan penggunaan lahan sawah menjadi permukiman di Kecamatan Tempel juga cukup tinggi. Kebutuhan permukiman di Kecamatan Tempel yang semakin tinggi membuat pemilik sawah merubah fungsi lahannya menjadi permukiman, seperti yang terdapat di Padukuhan Karang Ngabean, Desa Banyurejo, Kecamatan Tempel.

Tabel 1. Luas Perubahan Penggunaan Lahan tahun $2012-2018\left(\mathrm{Km}^{2}\right)$

\begin{tabular}{|c|c|c|c|c|c|c|c|}
\hline No & Perubahan Lahan & $\begin{array}{c}\text { Kec. } \\
\text { Ming-gir }\end{array}$ & $\begin{array}{c}\text { Kec. } \\
\text { Moyu- dan }\end{array}$ & $\begin{array}{c}\text { Kec. } \\
\text { Saye-gan }\end{array}$ & $\begin{array}{c}\text { Kec. } \\
\text { Gode-an }\end{array}$ & $\begin{array}{l}\text { Kec. } \\
\text { Mlati }\end{array}$ & $\begin{array}{c}\text { Kec. } \\
\text { Tem-pel }\end{array}$ \\
\hline 1 & Hutan menjadi Kebun & 0,08 & & 0,01 & 0,0 & - & 0,03 \\
\hline 2 & Hutan menjadi Pemukiman & 1,07 & 1,74 & 1,05 & 0,95 & 2,08 & 0,88 \\
\hline 3 & Hutan menjadi Lahan Terbuka & - & 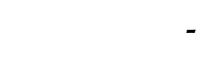 & 0,01 & 0,01 & 1,18 & \\
\hline 4 & Hutan menjadi Tegalan & 0,07 & - & - & 0,02 & 0,05 & 1,30 \\
\hline 5 & Hutan menjadi Sawah & 1,07 & 1,12 & 0,53 & 1,61 & 0,57 & 0,79 \\
\hline 6 & Kebun menjadi Hutan & 1,33 & 1,89 & 0,85 & 0,37 & 0,00 & 1,13 \\
\hline 7 & Kebun menjadi Pemukiman & 0,09 & 0,44 & 0,29 & 0,13 & 0,52 & 0,26 \\
\hline 8 & Kebun menjadi Sawah & 0,11 & 0,24 & 0,18 & 1,17 & 0,11 & 0,36 \\
\hline 9 & Kebun menjadi Tegalan & 0,02 & - & - & 0,00 & 0,00 & 0,71 \\
\hline 10 & Kebun menjadi Lahan Terbuka & - & - & 0,04 & 0,09 & 0,68 & \\
\hline 11 & Sawah menjadi Kebun & 0,12 & - & 0,01 & 0,04 & - & 0,02 \\
\hline 12 & Sawah menjadi Pemukiman & 0,29 & 0,94 & 1,35 & 1,16 & 2,45 & 1,28 \\
\hline 13 & Sawah menjadi Lahan Terbuka & - & - & 0,01 & - & 2,01 & \\
\hline 14 & Sawah menjadi Tegalan & 0,20 & - & 0,04 & 0,04 & 0,04 & 1,95 \\
\hline 15 & Sawah menjadi Hutan & 1,82 & 2,90 & 4,24 & 1,40 & 0,00 & 4,69 \\
\hline 16 & Tegalan menjadi Hutan & 0,41 & 0,65 & 0,05 & 0,05 & - & 0,23 \\
\hline 17 & Tegalan menjadi Pemukiman & 0,01 & 0,11 & - & 0,01 & 0,67 & 0,10 \\
\hline 18 & Tegalan menjadi Sawah & 0,03 & 0,15 & 0,04 & 0,19 & 0,02 & 0,16 \\
\hline 19 & Tegalan menjadi Lahan Terbuka & - & - & 0,02 & 0,01 & 0,14 & \\
\hline
\end{tabular}

Sumber: Hasil analisis, 2019 
Hasil analisis perubahan penggunaan lahan pada 6 kecamatan yang terdapat di Kawasan Keamanan dan Ketahanan Pangan Kabupaten Sleman dipicu oleh faktor ekonomi. Pemilik lahan mengubah fungsi lahan yang dimiliki dengan tujuan untuk mendapatkan keuntungan ekonomi. Sebagai contohnya perubahan lahan sawah dan kebun menjadi hutan produksi di daerah penelitian dipicu oleh rendahnya produktivitas hasil pertanian sawah dan kebun. Rata-rata produksi padi sawah di Kabupaten Sleman menurun dari 65,53 kw/Ha di Tahun 2015 menjadi 61,82 kw/Ha di Tahun 2016, (BPS, 2017). Penurunan produksi padi didaerah penelitian, dipengaruhi oleh faktor hama. Hama tikus menjadi endemik di Kecamatan Moyudan, Minggir, Sayegan, dan Godean

Turunnya produktivitas pertanian padi membuat para petani mengalih fungsikan lahan sawah dan kebun yang dimiliki menjadi tanaman keras atau tanaman tahunan (hutan produksi). Adapun jenis tanaman tahunan yang banyak ditanam oleh petani adalah pohon sengon, jati, dan mahoni. Jenis tanaman tersebut dirasa lebih menguntungkan karena tidak membutuhkan perawatan yang susah dan harga jual kayunya cukup tinggi.

\section{KESIMPULAN}

Perubahan penggunaan lahan pada Kawasan Keamanan dan Ketahanan Pangan Kabupaten Sleman mencapai $57,33 \mathrm{~km}^{2}$ atau $33,93 \%$ dari tahun 2012 sampai tahun 2018. Perubahan penggunaan lahan didominasi oleh perubahan lahan sawah menjadi hutan seluas $15,05 \mathrm{~km}^{2}$. Faktor pendorong adanya perubahan penggunaan lahan tersebut adalah produktivitas pertanian sawah yang semakin menurun tiap tahunnya. Akibatnya banyak pemilih lahan sawah yang mengubah fungsi sawah menjadi peruntukan lain,seperti hu-

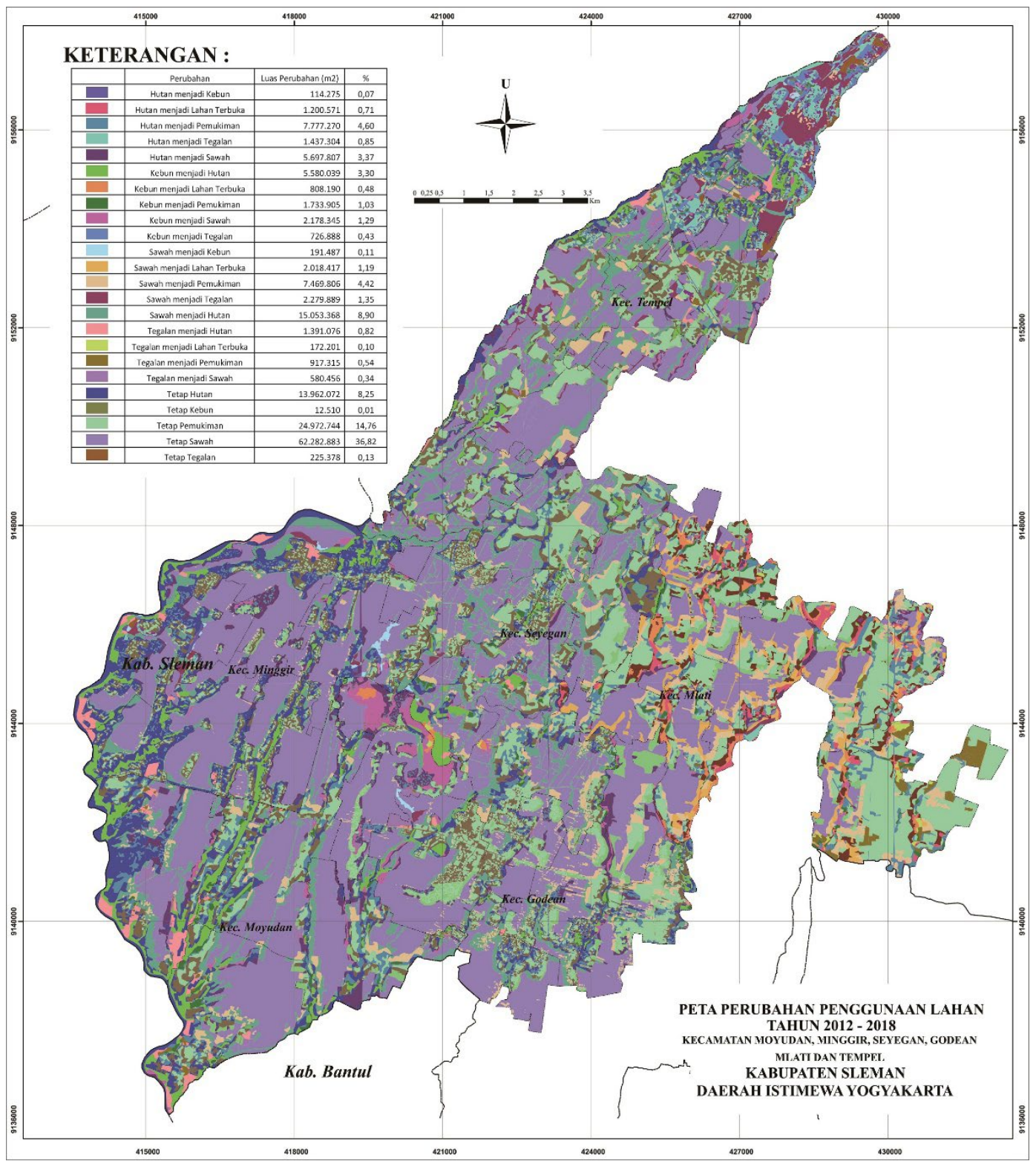

Gambar 4. Peta Perubahan Penggunaan Lahan Hutan tahun 2012 - 2018 
Farida Afriani Astuti \& Herwin Lukito, Perubahan Penggunaan Lahan di Kawasan Keamanan dan Ketahanan Pangan...

tan produksi, permukiman, kebun, dan tegalan. Perubahan penggunaan lahan tersebut dilakukan untuk mendapatkan keuntungan ekonomi yang lebih besar jika dibandingkan tetap mempertahan fungsinya sebagai lahan sawah. Perubahan penggunaan lahan pertanian pada Kawasan Keamanan dan Ketahanan Pangan yang tidak terkontrol akan berdampak pada ketersediaan dan ketahanan pangan di Kabupaten Sleman.

\section{UCAPAN TERIMAKASIH}

Ucapan terimakasih kami haturkan kepada Lembaga Penelitian dan Pengabdian Masyarakat (LPPM) UPN "Veteran" Yogyakarta karena kegiatan penelitian ini dibiayai sepenuhnya dari hibah Penelitian Internal dengan Perjanjian Pelaksanaan Pengabdian Nomor: B/136/UN.62/PT/V/2019. Ucapan terimakasih juga kami haturkan kepada masyarakat di Kabupaten Sleman yang sudah berperan aktif untuk memberikan dukungan terhadap kelancaran dan kesuksesan kegiatan penelitian ini. Semoga kegiatan yang sudah dilakukan ini dapat bermanfaat.

\section{DAFTAR PUSTAKA}

Badan Ketahanan Pangan Kementerian Pertanian. 2018. Indeks Ketahanan Pangan Indonesia 2018: Peringkat dan Skor
Indeks Ketahanan Pangan Kabupaten 2018. Kementerian Pertanian: Jakarta

Badan Pusat Statistik Kabupaten Sleman, 2017. Luas Panen, Produksi, dan Rata-Rata Produksi Padi Sawah dirinci per Kecamatan di Kabupaten Sleman, Tahun 2016. Badan Pusat Statistik: Kabupaten Sleman.

Habibatussolikhah, Annisa Titias., Darsono., Suci Wuri Ani. 2016. Analisis Faktor yang Mempengaruhi Alih Fungsi Lahan Sawah ke Non Sawah Di Kabupaten Sleman Daerah Istimewa Yogyakarta. Jurnal SEPA (Sosial Ekonomi Pertanian dan Agribisnis). 13(1),22-27.

Kundu, S., Khare, D., \& Mondal, A. (2017). Ecological Informatics Landuse change impact on sub-watersheds prioritization by analytical hierarchy process ( AHP ). Ecological Informatics, 42(1),100-113. https://doi. org/10.1016/j.ecoinf.2017.10.007

Nasir, M. 2005. Metode Penelitian. Ghalia Indonesia. Bogor

Nie, W., Yuan, Y., Kepner, W., Nash, M. S., Jackson, M., \& Erickson, C. (2011). Assessing impacts of Landuse and Landcover changes on hydrology for the upper San Pedro watershed. Journal of Hydrology, 407(1-4),105-114. https://doi.org/10.1016/j.jhydrol.2011.07.012

Peraturan Daerah Kabupaten Sleman Nomor 12 tahun 2012 Tentang Rencana Tata Ruang Wilayah (RTRW) Kabupaten Sleman Tahun 2011 - 2031

Pontoh, Nia K.,dan Iwan, Kustiawan. 2009. Pengantar Perencanaan Perkotaan. Penerbit ITB: Bandung.

Rizkiani, Happy., dan Sudrajat. 2015. Hubungan Alih Fungsi Lahan Pertanian Sawah dengan Ketersediaan Pangan Di Kabupaten Sleman dan Kabupaten Bantul Daerah Istimewa Yogyakarta. Jurnal Bumi Indonesia. 4(3).

Undang Undang Republik Indonesia Nomor 41 Tahun 2009 Tentang Perlindungan Lahan Pertanian Pangan Berkelanjutan. 